\title{
FINANCIAL WELL-BEING OF THE BENEFICIARIES OF THE MINHA CASA MINHA VIDA PROGRAM: PERCEPTION AND ANTECEDENTS
}

\author{
KELMARA M. VIEIRA ${ }^{1}$ \\ (D) https://orcid.org/0000-0002-8847-0941 \\ AURELIANO A. BRESSAN ${ }^{2}$ \\ (iD) https://orcid.org/0000-0002-9333-3394 \\ LUANA S. FRAGA ${ }^{3}$ \\ (iD) https://orcid.org/v0000-0002-5115-6502
}

\begin{abstract}
To cite this paper: Vieira, K. M., Bressan, A. A., \& Fraga, L. S. (2021). Financial well-being of the beneficiaries of the Minha Casa Minha Vida program: Perception and antecedents. Revista de Administração Mackenzie, 22(2), 1-40. doi:10.1590/1678-6971/eRAMG210115
\end{abstract}

Submission: June 6, 2019. Acceptance: Apr. 14, 2020.

\footnotetext{
Federal University of Santa Maria (UFSM), Santa Maria, RS, Brazil.

2 Federal University of Minas Gerais (UFMG), Belo Horizonte, MG, Brazil.

3 Pontifical Catholic University of Rio Grande do Sul (PUCRS), Porto Alegre, RS, Brazil.
}

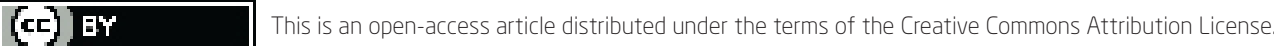

\footnotetext{
This paper may be copied, distributed, displayed, transmitted or adapted for any purpose, even commercially, if provided, in a clear and explicit way, the name of the journal, the edition, the year and the pages on which the paper was originally published, but not suggesting that RAM endorses paper reuse. This licensing term should be made explicit in cases of reuse or distribution to third parties.

Este artigo pode ser copiado, distribuído, exibido, transmitido ou adaptado para qualquer fim, mesmo que comercial, desde que citados, de forma clara e explícita, o nome da revista, a edição, o ano e as páginas nas quais o artigo foi publicado originalmente, mas sem sugerir que a RAM endosse a reutilização do artigo. Esse termo de licenciamento deve ser explicitado para os casos de reutilização ou distribuição para terceiros.
} 


\section{ABSTRACT}

Purpose: This article has two main objectives: to measure the level of financial well-being (FWB) of the beneficiaries of the Minha Casa Minha Vida program (PMCMV) and test the hypothesis that financial literacy is an antecedent of the FWB.

Originality/value: Considering that there is still no universally accepted definition and measure for the FWB (Brüggen, Hogreve, Holmlund, Kabadayi, \& Löfgren, 2017), this study seeks to apply the methodology proposed by the Consumer Financial Protection Bureau (CFPB) in Brazil, since the previous applications attempts of other scales showed great instability. Also, the hypothesis that the financial literacy is a antecedent of the FWB is tested.

Design/methodology/approach: To measure the FWB, the scale developed by the CFPB was used. Financial literacy was built from the three dimensions proposed by the Organisation for Economic Co-operation and Development (OECD), which are: financial behavior, attitude and financial knowledge. The instrument was implemented in 561 beneficiaries of the three funding ranges of the PMCMV. It was used for descriptive statistical analysis, confirmatory factorial analysis and multiple linear regression.

Findings: The results indicated that the majority of the beneficiaries of the program present medium-low and medium-high levels of FWB. The hypothesis that financial literacy is an antecedent of the FWB was confirmed, and all three dimensions had a positive impact. Levels of income also presented a positive influence, whereas the fact of having dependents had a negative impact. The BEF measure proposed by the CFPB seems adequate to the Brazilian context. And advances in the national financial literacy strategies tend to increase the FWB of the Minha Casa Minha Vida program.

\section{KEYWORDS}

Financial well-being. Minha Casa Minha Vida program. Financial literacy. Financial protection. Well-being scale. 


\section{INTRODUCTION}

Although financial well-being (FWB) is becoming a topic of interest in several areas, including economics, financial planning, psychology, and consumer decision-making, there is still no universally-accepted definition or measure of it in the literature (Brüggen, Hogreve, Holmlund, Kabadayi, \& Löfgren, 2017). Thus, several studies that analyze FWB are not concerned with presenting a definition (Guo, Arnould, Gruen, \& Tang, 2013; O’Neill, Sorhaindo, Xiao, \& Garman, 2005; Prawitz et al., 2006, Shim, Xiao, Barber, \& Lyons, 2009; Guo, Arnould, Gruen, \& Tang, 2013). Studies with definitions, however, use different approaches (whether objective or subjective).

In the objective approach, income, financial information, financial indexes (Joo \& Grable, 2004; Kahneman \& Deaton, 2010) and liquidity (Aggarwal, 2014) are used as proxies for FWB. Using the subjective approach, researchers seek to examine people's perceptions and reactions to their financial conditions (Norvilitis, Szablicki, \& Wilson, 2003; O’Neill et al., 2005). Thus, individuals in similar financial situations (in terms of financial assets or income profile) may perceive their FWB differently, depending on their preferences. Thus, people in the same financial situation can assess their well-being differently (Garman, Sorhaindo, Bailey, Kim, \& Xiao, 2004).

In these studies, personal characteristics (Joo \& Grable, 2004) and behavioral factors (Shim et al., 2009) that affect the subjective evaluation of FWB become relevant. In this context, different perceptions can also arise as a function, for example, of the stage of life (Malone, Stewart, Wilson, \& Korsching, 2010) or of the attitude towards risk, the perceived capacity to satisfy expenses, satisfaction with savings and investment, and the tendency to worry about debt (Kim, Garman, \& Sorhaindo, 2003).

There are also studies that use both approaches, that is, FWB is treated as a concept composed of objective and subjective dimensions (Vosloo, Fouche, \& Barnard, 2014; Mende \& Van Doorn, 2015). In these cases, the literature uses different indicators for each of the dimensions, including the level of indebtedness and/or the level of income as a measure of objective wellbeing and satisfaction with their financial status or with their standard of living as a subjective measure.

Some empirical evidence already point to the difficulty of direct application to developing countries of the scales proposed internationally. Brüggen et al. (2017) highlights that, although FWB definitions and measures are 
not exclusively applicable to industrialized countries, the meaning of the expression is quite different for developing countries, where a large part of the population struggles to survive. Especially in the Brazilian case, three independent studies (Kunkel, Vieira, \& Potrich 2015; Campara, Vieira, \& Potrich, 2017, Santos, Mendes-Da-Silva, Flores, \& Norvilitis, 2016), with different samples, but using the scale proposed by Norvilitis et al. (2003), maintained in their analysis only three of the eight questions that constituted the original scale.

Despite the different conceptualizations and forms of measurement, several studies present evidence that FWB is associated with demographic and socioeconomic variables, as well as other behavioral factors. Gender, ethnicity, age, income, education and marital status (Hira \& Mugenda, 1999; Chan, Omar, \& Yong, 2018) are examples of some of these variables of interest, along with financial literacy as a major behavioral factor (Joo \& Grable, 2004; Shim et al., 2009; Huston, 2010; Adam, Frimpong, \& Boadu, 2017, among others).

The importance of financial literacy for FWB is already recognized by international organizations. Both the Organisation for Economic Co-operation and Development (OECD) and the Consumer Financial Protection Bureau (CFPB) claim that the measure of success for financial literacy efforts must be FWB. In this context, financial literacy is a combination of awareness, knowledge, skill, attitude and behavior necessary to make sound financial decisions, and thus make it possible to achieve individual FWB (OECD, 2013a; CFPB, 2015a).

Brazil, in line with these international organizations, has sought to establish strategies to improve financial education. In 2010, the country instituted the National Strategy for Financial Education (Estratégia Nacional de Educação Financeira - ENEF), which aims to "promote financial and social security education and contribute to the strengthening of citizenship, the efficiency and soundness of the national financial system and conscious decision making on the part of consumers" (translated to English from Brasil, 2010). In addition, financial education was included among the suggested themes to compose the National Common Curricular Base (BNCC), a document that defines the set of essential skills that all students should develop throughout the stages and modalities of the country's basic education (Brasil, 2018).

However, in the latest survey of Programme for International Student Assessment (Pisa), Brazil presented the worst performance in financial literacy among all OECD countries participating in the assessment. Specifically, only 
$3 \%$ of students age 15 in Brazil registered proficiency at the maximum level, compared with $12 \%$, on average of students worldwide (OECD, 2018).

In this context, this article has two main purposes: 1. to measure the level of FWB of the beneficiaries of the Minha Casa Minha Vida Program (PMCMV), and 2. to test the hypothesis that Financial Literacy is an antecedent of FWB. The choice of this target audience is justified by the fact that those low-income families eligible to apply for a loan in the program assume a long-term debt that represents a significant proportion in relation to their income. Given the rules of participation, the program allows families whose benefits can compromise up to $20 \%$ of the family income for a period that can last up to ten years.

The hypothesis that financial literacy is an antecedent of FWB finds support in the argument that the measure of success for financial literacy efforts must be financial well-being (OECD, 2013a; CFPB, 2015a). It is also supported by evidence suggesting that financial behavior (Delafrooz \& Paim, 2011; Mokhtar \& Husniyah, 2017) and financial attitudes (Joo, 2008) are positively related to FWB. For financial knowledge, there is also ample evidence of a positive and significant effect (Joo \& Grable, 2004; Delafrooz \& Paim, 2011; Robb \& Woodyard, 2011; Falahati, Sabri, \& Paim, 2012; Banco Central do Brasil [BCB], 2017).

It is understood that, in the case of public policies - especially those involving transfers of resources and/or financial subsidies, as is the case with the PMCMV - the FWB must be among the objectives of the policy and, therefore, must be included in the dimensions of evaluation of the program. In addition, as Brazil evolves in the adoption of national financial literacy strategies, such as Enef and, considering that the ultimate goal of financial literacy should be financial well-being, a measure of the individuals' FWB level becomes relevant. In addition, an FWB indicator can assist in the analysis of the evolution of the level of well-being and, consequently, assist in the definition of priority areas of action for inclusion and financial education programs in different population profiles.

In addition to this introduction, the article is structured as follows. In section 2, the theoretical foundations of FWB and financial literacy are presented. Then, section 3 highlights the sample, the instrument, and the analysis techniques. Section 4 describes the profile of respondents, descriptive statistics, the process of measuring the level of FWB and the analysis of the influence of financial literacy on FWB. Section 5 presents the main conclusions and implications for the formulation of public financial education policies. 


\section{THEORETICAL BACKGROUND}

\subsection{Financial well-being}

Among the definitions of FWB, one of the most used is the one of the CFPB (2015a) in which the FWB can be defined as a state in which the individual is able to meet his current and ongoing financial obligations, feeling secure about his financial future and is able to make choices that allow him to enjoy life. In this sense, Plagnol (2011) states that the ability to effectively manage monetary resources, in favor of a financial balance capable of providing economic stability is an important factor for all individuals and when this stability is achieved, FWB is attained. A similar definition is proposed by Arber, Fenn, and Meadows (2014), in which the FWB is the classification obtained by the individual in relation to the perception of satisfaction regarding the adequacy of their income in relation to their personal needs. Brüggen et al. (2017) add to the concept the idea of financial freedom, that is, the ability of individuals to make decisions about their lives without worrying about their financial restrictions, leading then to FWB. Joo (2008) shows that FWB is an anxiety-free, healthy and happy financial perception. And yet, in a more synthetic way, Shim et al. (2009) define FWB simply as the positive feeling regarding the individual's financial situation.

In an attempt to better specify the concept, the CFPB (2015a) defined as resources inherent to an individual's FWB: 1. having control over their finances, being able to meet expenses on time; 2 . having a financial reserve in case of unexpected expenses and emergencies, in addition to having health insurance, good credit condition, and being able to count on friends and family if you need any extra financial assistance; 3 . having goals, such as saving a monthly amount of resources for retirement and being on track to achieve your goals; 4 . being able to make choices that allow you to enjoy life, such as taking a vacation, enjoying leisure time, returning to a school to pursue a more advanced degree of study or working less to spend more time with your family.

Chan, Chan, and Chau (2012) and Malone et al. (2010) also argue that, in order to understand FWB, it is necessary to take into consideration individuals' understanding and temporal concern about the past, present, and future, that is, aspects related to past financial experiences, current experiences and future expectations. In this perspective, Delafrooz and Paim (2011) complement this argument, stating that the FWB must contemplate 
financial satisfaction, the perception of financial resources, financial stability, and the objective value of assets.

Thus, in order to identify people's financial satisfaction, it is necessary to analyze the context of life in which they live and, consequently, the family's disposable income. Thus, the greater the debt in relation to income, the lower the financial satisfaction tends to be. Therefore, an increase in income will not always translate into an increase in financial satisfaction, since the level of debt may be high and, consequently, it will affect FWB (Vlaev \& Elliott, 2014). However, other factors such as personality, attitude, decisionmaking context, opportunities, knowledge, skills, and behavior can also affect the perception of the financial situation (CFPB, 2015a).

Regarding ways of assessing the level of FWB, during the 1990s more objective aspects were taken into account, related to: family income, budget items (expenses with food, clothing, housing, and transportation), financial resources available to handle emergencies, net worth (difference between assets and all debts), the amount of household debt, the level of savings, and money for future needs (Samarian, 1990; Lown \& Ju, 1992). Over the years, this objective perspective on FWB has given rise to subjective aspects. The discussion about FWB, then, incorporates aspects related to the personal characteristics of each individual. Some of these are their values, experiences, expectations and disposition, which reflect significantly in the global sense or perception of FWB.

In this approach, the international FWB scales developed by Norvilitis et al. (2003), the proposal by Prawitz et al. (2006), called Personal Financial Wellness Scale $^{\mathrm{TM}}$ (PFW Scale ${ }^{\mathrm{TM}}$ ) and, more recently, the instrument released by CFPB (2015a) are the most cited proposals in the literature.

The FWB scale by Norvilitis et al. (2003) consists of eight items designed to measure feelings of confidence and financial security, scored on a 5-point scale ranging from 1 (strongly agree) to 5 (strongly disagree). The scale comprises two main factors: current financial concerns and expectations for the future. The PFW Scale is composed of eight questions, which measure how people declare themselves about financial reactions and situations, using a 10-point likert-type scale, ranging from negative feelings to positive feelings (Prawitz et al., 2006).

The scale, developed by the CFPB (2015a), is based on the insights of consumers and experts and was developed using techniques such as interviews and psychometric tests, to ensure an accurate understanding of the questions. The scale has 10 items that incorporate the four elements of the FWB, as summarized in Figure 2.1.1. 


\section{(Figure 2.1.1)}

MAIN ELEMENTS OF FWB IN THE PRESENT AND THE FUTURE

\begin{tabular}{lll}
\hline \multicolumn{1}{c}{ Components } & \multicolumn{1}{c}{ Present } & \multicolumn{1}{c}{ Future } \\
\hline Security & Control over day-to-day finances. & $\begin{array}{l}\text { Ability to deal with a financial } \\
\text { setback. }\end{array}$ \\
\hline Freedom of choice & Freedom in financial choices to enjoy life. & $\begin{array}{l}\text { To be on track to achieve your } \\
\text { financial goals. }\end{array}$ \\
\hline
\end{tabular}

Source: Adapted from CFPB (2015a).

There are still few studies that tried to apply FWB scales in Brazil; the three studies that used the Norvilitis et al. (2003) scale ended up excluding most questions from the analysis. Kunkel et al. (2015), Santos et al. (2016), and Campara et al. (2017), based on confirmatory factor analysis, maintained in their studies only three questions from the eight proposals. The other questions were excluded from the models due to a lack of significance or very low coefficients.

Regarding the differences in FWB, the literature brings changes for several socioeconomic and demographic variables. Figure 2.1.2 provides a description of those used.

\section{(Figure 2.1.2)}

SUMMARY OF THE RELATIONSHIPS BETWEEN SOCIOECONOMIC AND DEMOGRAPHIC VARIABLES AND FWB

\begin{tabular}{lll}
\multicolumn{1}{c}{ Variable } & \multicolumn{1}{c}{ Expected relationship } & \multicolumn{1}{c}{ Authors } \\
Gender & $\begin{array}{l}\text { Men have higher levels of financial well- } \\
\text { being. }\end{array}$ & $\begin{array}{l}\text { Shim et al. (2009), Gutter and Copur } \\
\text { (2011), and Leach, Hayhoe, and Turner } \\
(1999)\end{array}$ \\
\hline \multirow{2}{*}{ Dependents } & $\begin{array}{l}\text { Dependents at home negatively } \\
\text { influence FWB. }\end{array}$ & Penn (2007) and Kunkel (2014) \\
\hline \multirow{2}{*}{ Age } & $\begin{array}{l}\text { Older individuals have greater financial } \\
\text { well-being compared to younger ones. }\end{array}$ & $\begin{array}{l}\text { Sumarwan (1990), Xiao, Sorhaindo, and } \\
\text { Garman (2006), Plagnol (2011) and } \\
\text { Kunkel (2014) }\end{array}$ \\
\hline \multirow{2}{*}{ Marital status } & Married individuals have a higher FWB. & $\begin{array}{l}\text { Sumarwan (1990) and Diniz, Vieira, } \\
\text { Potrich, and Campara (2014, 2015) }\end{array}$ \\
\cline { 2 - 3 } & Single individuals have higher FWB. & Gutter and Copur (2011) \\
\hline
\end{tabular}




\section{(Figure 2.1.2 (conclusion))}

SUMMARY OF THE RELATIONSHIPS BETWEEN SOCIOECONOMIC AND DEMOGRAPHIC VARIABLES AND FWB

\begin{tabular}{|c|c|c|}
\hline Variable & Expected relationship & Authors \\
\hline \multirow{2}{*}{ Education } & $\begin{array}{l}\text { Individuals with a higher educational } \\
\text { level tend to have a higher FWB. }\end{array}$ & $\begin{array}{l}\text { Lown and Ju (1992), Diniz et al. (2014, } \\
\text { 2015), and Penn (2007) }\end{array}$ \\
\hline & $\begin{array}{l}\text { Individuals with a lower educational } \\
\text { level tend to have a higher FWB. }\end{array}$ & Plagnol (2011) \\
\hline Income & $\begin{array}{l}\text { Individuals with higher income levels } \\
\text { have higher FWB. }\end{array}$ & $\begin{array}{l}\text { Sumarwan (1990), Delafrooz and Paim } \\
\text { (2011), Gutter and Copur (2011), Penn } \\
\text { (2007), Kunkel (2014), Diniz et al. } \\
\text { (2014), and Vlaev and Elliott (2014) }\end{array}$ \\
\hline
\end{tabular}

Source: Elaborated by the authors.

Figure 2.1.2 shows the variables marital status and education, for which there is no consensus in the literature regarding the relationship with FWB. With regard to marital status, Sumarwan (1990) and Diniz, Vieira, Potrich, and Campara (2014) concluded that married individuals are more likely to be satisfied with the resources and assets they have in relation to single, divorced, or widowed individuals. On the other hand, Gutter and Copur (2011) affirmed in their work on FWB with university students that singles have significantly greater FWB in relation to married, divorced or widowed people.

As for education, Lown and Ju (1992) and Diniz et al. (2014) demonstrated that there are significant differences regarding level of education and its influence on FWB, with groups with a higher educational level tending to be more satisfied. Corroborating the idea that educational level positively influences the perception of FWB, Penn (2007) demonstrated that individuals with formal education (in this case, university degrees) had a better perception of FWB in relation to individuals without a university degree. On the other hand, Plagnol (2011) reports that individuals with a higher level of education have higher aspirations and, therefore, are less satisfied with their financial situation.

\subsection{Financial literacy as an antecedent of financial well-being}

Although there are several definitions for financial literacy, the representativeness of the three dimensions developed by the OECD (2015) stands 
out: 1. the knowledge and understanding of financial concepts and risks; 2. skills, motivation, and confidence to apply this knowledge; and 3. understanding, in order to make effective decisions in a variety of contexts so that the FWB of individuals and society is maximized (OECD, 2015).

The dimension of financial knowledge or financial education can be defined as a particular type of human capital, acquired throughout life and related to the ability to effectively manage income, expenses, and savings (Delavande, Rohwedder, \& Willis, 2008). In other words, financial knowledge can be understood as the ability of an individual to understand financial information linked to operational credit, savings, investment and consumption transactions, compatible with his/her financial reality (Huston, 2010).

Financial behavior is the last dimension of financial literacy, mentioned by the OECD (2013a). It is considered an essential element among the three, as it materializes financial balance or imbalance. Adequate financial behavior has, at least, five requirements: honoring monthly expenses, keeping finances under control, planning for the future, making assertive choices regarding financial products, and keeping abreast of financial issues (Mundy, 2011).

\section{RESEARCH METHOD}

\subsection{Participants}

The target population of the study consists of people who received loans by the PMCMV, belonging to various financing ranges. In range 1, families are selected by the municipality or state government. They cannot own property and have not previously received housing benefits from the federal government. The debt amortization period is fixed at 120 months, in which the gross amount of the installment corresponds to that of the financing divided by 120 . The net amount of installments to be paid by the beneficiary corresponds to $5 \%$ of the gross monthly family income or $\mathrm{R} \$ 25.00$, whichever is greater; the remaining amount is subsidized by the program (Caixa Econômica Federal [CEF], 2015a). Families with incomes between $\mathrm{R} \$ 1,600.01$ and $\mathrm{R} \$ 3,275.00$ per month belong to the PMCMV's range 2 (which offers subsidies and reduced interest). Families with income between $\mathrm{R} \$ 3,275.01$ and $\mathrm{R} \$ 5,000.00$ belong to range 3 and have only reduced interest rates when compared to the other groups.

In ranges 2 and 3, the amount financed is defined according to an analysis of the beneficiary's payment capacity. This follows a risk assessment conducted by the Caixa Econômica Federal (Brazil's public bank dedicated to 
mortgages and real estate financing), respecting the limits of gross family income and investment value, applicable individually, to the units that are part of the project, also observing the percentage of the borrower's minimum participation in the investment, the amortization system / term and the interest rate (CEF, 2015a).

Subsidies may be for the purpose of covering the remuneration of the financial agent, with a reduction in the value of the installments or for the purpose of paying part of the acquisition or construction of the property. A discount on the monthly interest rate of beneficiary financing is granted within the established income limits, calculated based on the theoretical flow of financing over the term of the operation, varying between $5 \%$ and $7.16 \%$ per year (CEF, 2015b).

As opposed to range 1, the beneficiaries of ranges 2 and 3 cannot have any registration limitation, and must be approved in the credit risk analysis. In addition, recipients cannot hold active financing in the Brazilian Housing Financial System or be the owner, assignee, or promising buyer (or even the holder of the right to acquire another urban residential property located in the current place of residence or where he/she intends to fix it).

The study sample comprised 561 beneficiaries from the three financing ranges, residing in three different cities in the state of Rio Grande do Sul. The respondents were interviewed at their homes, upon agreeing to participate in the research. Of the 561 respondents, 170 (30.3\%) obtained financing in range 1 (income up to $\mathrm{R} \$ 1,600.00), 368(65.6 \%)$ in range 2 (income up to $\mathrm{R} \$ 3,275.00$ ) and $23(4.15 \%$ ) in range 3 (income up to $\mathrm{R} \$ 5,000.00$ ). Figure 3.1.1 presents the profile of the respondents.

\section{(Figure 3.1.1)}

PROFILE OF RESPONDENTS ACCORDING TO THE VARIABLES: AGE, GENDER, MARITAL STATUS, DEPENDENTS, EDUCATION, WHO WORKS

IN THE FAMILY, WHO CONTRIBUTES TO HOUSEHOLD EXPENSES, OCCUPATION, AND INCOME

\begin{tabular}{lllcc}
\multicolumn{1}{c}{ Variables } & \multicolumn{1}{c}{ Alternatives } & Frequency & Percentage \\
\hline \multirow{3}{*}{ Age } & Up to 29 years & 147 & 26.2 \\
\cline { 2 - 5 } & From 30 to 36 years & 144 & 25.7 \\
\cline { 2 - 5 } & From 37 to 48 years & 142 & 25.3 \\
\cline { 2 - 4 } & Above 48 years & 128 & 22.8 \\
\hline
\end{tabular}




\section{(Figure 3.1.1 (continuation))}

PROFILE OF RESPONDENTS ACCORDING TO THE VARIABLES: AGE, GENDER, MARITAL STATUS, DEPENDENTS, EDUCATION, WHO WORKS IN THE FAMILY, WHO CONTRIBUTES TO HOUSEHOLD EXPENSES, OCCUPATION, AND INCOME

\begin{tabular}{|c|c|c|c|}
\hline Variables & Alternatives & Frequency & Percentage \\
\hline \multirow{2}{*}{ Gender } & Male & 184 & 32.8 \\
\hline & Female & 377 & 67.2 \\
\hline \multirow{4}{*}{ Marital status } & Married & 349 & 62.3 \\
\hline & Single & 138 & 24.6 \\
\hline & Widowed & 24 & 4.3 \\
\hline & Separated & 49 & 8.8 \\
\hline \multirow{2}{*}{ Has dependents } & No & 263 & 47.6 \\
\hline & Yes & 290 & 52.4 \\
\hline \multirow{8}{*}{ Education level } & I never studied. & 7 & 1.3 \\
\hline & Elementary school from 1st to 4th grade & 69 & 12.4 \\
\hline & Elementary school from 5th to 9th grade & 74 & 13.3 \\
\hline & High school & 218 & 39.1 \\
\hline & Technical course & 38 & 6.8 \\
\hline & Faculty (higher education) & 114 & 20.5 \\
\hline & Specialization or MBA & 23 & 4.1 \\
\hline & Masters/doctorate/postdoctorate & 14 & 2.5 \\
\hline \multirow{7}{*}{$\begin{array}{l}\text { Who works in your } \\
\text { family? }\end{array}$} & You & 129 & 24 \\
\hline & Your partner & 61 & 11.3 \\
\hline & You and your partner & 258 & 48 \\
\hline & Your children/grandchildren & 18 & 3.3 \\
\hline & You, your partner, and your children/grandchildren & 18 & 3.3 \\
\hline & Other people & 44 & 8.2 \\
\hline & Nobody & 10 & 1.9 \\
\hline
\end{tabular}




\section{(Figure 3.1 .1 (conclusion))}

PROFILE OF RESPONDENTS ACCORDING TO THE VARIABLES: AGE, GENDER, MARITAL STATUS, DEPENDENTS, EDUCATION, WHO WORKS IN THE FAMILY, WHO CONTRIBUTES TO HOUSEHOLD EXPENSES, OCCUPATION, AND INCOME

\begin{tabular}{|c|c|c|c|}
\hline Variables & Alternatives & Frequency & Percentage \\
\hline \multirow{7}{*}{$\begin{array}{l}\text { Who contributes } \\
\text { to the household } \\
\text { expenses? }\end{array}$} & You & 144 & 25.9 \\
\hline & Your partner & 57 & 10.3 \\
\hline & You and your partner & 272 & 48.9 \\
\hline & Your children/grandchildren & 13 & 2.3 \\
\hline & You, your partner, and your children/grandchildren & 16 & 2.9 \\
\hline & Other people & 51 & 9.2 \\
\hline & Nobody & 3 & 0.5 \\
\hline \multirow{12}{*}{ Occupation } & Wage earner with a formal contract & 256 & 45.7 \\
\hline & Wage earner without a formal contract & 7 & 1.3 \\
\hline & Public agente & 55 & 9.8 \\
\hline & Regular freelance & 61 & 10.9 \\
\hline & Businessman & 15 & 2.7 \\
\hline & Free-lance & 20 & 3.6 \\
\hline & Housewife & 35 & 6.3 \\
\hline & Just retired & 44 & 7.9 \\
\hline & Only student & 6 & 1.1 \\
\hline & Unemployed (looking for a job) & 23 & 4.1 \\
\hline & Unemployed (not looking for a job) & 12 & 2.1 \\
\hline & Another & 25 & 4.5 \\
\hline \multirow{4}{*}{$\begin{array}{l}\text { Monthly family } \\
\text { income }\end{array}$} & Up to $\mathrm{R} \$ 1,600.00$ & 123 & 22 \\
\hline & From $R \$ 1,600.01$ to $R \$ 3,275.00$ & 233 & 41.7 \\
\hline & From $R \$ 3,275.01$ to $R \$ 5,000.00$ & 147 & 26.3 \\
\hline & Above $\mathrm{R} \$ 5,000.00$ & 56 & 10.0 \\
\hline
\end{tabular}


More than half the respondents were up to 36 years old; less than a quarter were older than 48 years old. These data show that most beneficiaries are younger and, with the PMCMV, were able to acquire their first property. Most respondents were female $(67.2 \%)$, married (62.3\%), and with high school $(39.1 \%)$ or higher education $(20.5 \%)$.

When asked about who works in the family, the highest percentages were in the alternatives "You and your partner" and "You". This was also found when respondents were asked about who contributes to household expenses. Here, $48.9 \%$ replied "You and your partner" and 25.9\% endorsed "You". As for occupation, a large part of the sample was comprised of employees with a formal contract, regular self-employed persons, civil servants, or only retired. Regarding monthly family income, most had a monthly family income of up to $\mathrm{R} \$ 3,275.00$.

\subsection{Instrument}

The questionnaire was composed of three blocks. The first, aimed at identifying the participants' profiles, had nine questions. The second block presents the FWB scale, whose questions were translated from the scale proposed by the CFPB (2015b). The scale consists of ten questions, divided into two parts. The first part is comprised of questions assessing whether the individual can handle unexpected expenses; guarantee his/her financial future; feeling that he/she will be able to acquire desired things; and enjoy life due to the way he/she manages personal finances. The variables in the second part asks whether the participant can save money, if there is a financial difficulty in the month when there is an unexpected event, if he is up to date with his finances and if finances control his life.

On the third block, there are the three dimensions of financial literacy. The financial behavior maintained by the respondents is assessed by adapting the scales proposed by Shockey (2002), O'Neill and Xiao (2012) and by the OECD (2013b). The purpose is to identify the level of financial behavior of individuals, whether they act in order to protect or risk their monetary resources, with variables related to the control of expenses, price comparison and savings. To measure financial attitude, a construct, whose design was based on the scales of Shockey (2002) and OECD (2013b) was used to identify how the individual evaluates his/her financial management. The more the respondent agrees with the statements made, the more positive their financial attitude. For financial knowledge, respondents are invited to think about financial issues and mark the alternative they consider correct; for 
each question, there is only one true alternative. Thus, an index will be built based on multiple choice questions adapted from Alessie, Van Rooij, and Lusardi (2011), Klapper, Lusardi, and Panos (2013), OECD (2013b), and the National Financial Capability Study - NFCS (2013).

The research instrument went through three stages before its application, namely: reverse translation, expert evaluation and pre-testing. This process was carried out in order to verify whether the semantics and questioning were consistent with the social context of these people, as well as whether the questions were really questioning what was intended to be investigated. The translation process was carried out by two people in three stages, the questions were translated from English to Portuguese, from Portuguese to English and finally into Portuguese again. The evaluation by specialists was carried out by three professionals with knowledge of the research area. The pre-test involved the application of the instrument to 20 beneficiaries.

The profile questions of the first block of the instrument can be identified in Figure 3.1.1; the other questions of the instrument are listed in Appendix.

\subsection{Analysis techniques}

As analysis techniques, we used descriptive statistical measures, confirmatory factor analysis and multiple regression analysis. However, before using statistical techniques, it was necessary to apply the methodology proposed by the CFPB (2015b) to calculate the FWB level of each participant. Thus, for each alternative answer, a score was assigned, and in the first part, in questions $22,23,25$, the answer alternatives are equivalent to: completely $=4$, very well $=3$, a little $=2$, very little $=1$ and not at all $=0$. In questions 24, 26 and 27, the answer alternatives are equivalent to the following score: completely $=0$, very well $=1$, a little $=2$, very little $=3$ and not at all $=4$. In the second part, in questions 28,30 and 31 , the alternatives are equivalent to: always $=0$, often $=1$, sometimes $=2$, rarely $=3$ and never $=4$. In question 29 , the score is given as follows: always $=4$, often $=3$, sometimes $=2$, rarely $=1$ and never $=0$. From the sum of the scores of all of the variables, we obtain the total score, which ranges from 0 to 40 , and the higher the score, the higher the FWB.

In addition to descriptive statistics, Confirmatory Factor Analysis is used to validate the constructs "financial attitude" and "financial behavior." To do so, it begins with a variance-covariance matrix and opts for the estimation of maximum likelihood via a direct procedure. 
The identification of construct validity and reliability are verified following the recommendation of Hair, Black, and Babin (2010). Thus, in addition to the magnitude and statistical significance of the standardized coefficients, the indicators in Figure 3.3.1 are used.

\section{(Figure 3.3.1)}

\section{DESCRIPTION OF THE ADJUSTMENT AND RELIABILITY INDICES FOLLOWED BY THEIR PURPOSES AND LIMITS}

\begin{tabular}{|c|c|c|}
\hline Adjustment indices & Purpose & Limits \\
\hline Chi-square (value) & \multirow{2}{*}{$\begin{array}{l}\text { - Significance of the differences between the observed } \\
\text { matrix }(\Sigma) \text { and the estimated matrix }(\Sigma \Theta) \text {. When the } \\
\text { sample is large, it tends to be significant, thus testing } \\
\text { Chi-square/degrees of freedom. }\end{array}$} & \multirow{2}{*}{$\begin{array}{l}\text { Chi-square/ } \\
\text { degrees of } \\
\text { freedom }<3\end{array}$} \\
\hline Chi-square (probability) & & \\
\hline Goodness of fit (GFI) & $\begin{array}{l}\text { - Represents the general degree of adjustment, not } \\
\text { being weighted in terms of degrees of freedom. }\end{array}$ & $>0.95$ \\
\hline Comparative fit index (CFI) & $\begin{array}{l}\text { - Global comparative measure between the estimated } \\
\text { and null models. }\end{array}$ & $>0.95$ \\
\hline Normed fit index (NFI) & $\begin{array}{l}\text { - Indicates the proportion in which the adjustment of } \\
\text { the proposed model is better than the adjustment } \\
\text { of the null model. }\end{array}$ & $>0.95$ \\
\hline Tucker-Lewis index (TLI) & $\begin{array}{l}\text { - It presents an interpretation similar to the NFI including } \\
\text { an adjustment measure for the complexity of the model. }\end{array}$ & $>0.95$ \\
\hline $\begin{array}{l}\text { Root mean square residual } \\
\text { (RMSR) }\end{array}$ & $\begin{array}{l}\text { - Compares the fit of two different models made from } \\
\text { the same database. }\end{array}$ & $<0.05$ \\
\hline $\begin{array}{l}\text { RMS error of approximation } \\
\text { (RMSEA) }\end{array}$ & $\begin{array}{l}\text { - Represents the discrepancy between the covariance } \\
\text { matrix observed and estimated by the degree of } \\
\text { freedom. }\end{array}$ & $<0.08$ \\
\hline Reliability & Purpose & Limits \\
\hline Reliability index & \multirow{2}{*}{$\begin{array}{l}\text { - Check the internal consistency of an aggregate scale } \\
\text { based on the average correlation between the pairs of } \\
\text { indicators. }\end{array}$} & \multirow{2}{*}{$>0.6$} \\
\hline Cronbach's alpha & & \\
\hline
\end{tabular}

Source: Elaborated by the authors based on Byrne (2010), Hair et al. (2010), Hooper, Coughlan, and Mullen (2008), and Kline (2011).

Unidimensionality is assessed based on the standardization of residuals related to the indicators of each latent variable. Constructs that have, for a $5 \%$ significance level, standardized residues below 2.58 are considered onedimensional (Hair et al., 2010). 
Finally, a multiple linear regression model is used to analyze the influence of financial literacy on FWB. The FWB score is computed according to the methodology proposed by the CFPB (2015b), as previously described. Financial behavior is the sum of the correct answers to the questions that make up the construct. The financial attitude and behavior are computed by the weighted average of the answers to the questions. The standardized factorial loads obtained in the validation of the constructs are used as weights. Figure 3.3.2 presents the description of the independent variables:

\section{(Figure 3.3.2) \\ DESCRIPTION OF THE INDEPENDENT VARIABLES OF THE REGRESSION MODEL}

\begin{tabular}{|c|c|}
\hline Variables & Description \\
\hline Financial behavior & $\mathrm{Q} 14^{\star} 0,120+\mathrm{Q} 16^{\star} 0,121+\mathrm{Q} 17^{\star} 0,252+\mathrm{Q} 18^{\star} 0,267+\mathrm{Q} 19^{\star} 0,240$ \\
\hline Financial attitude & Q23i*0,266+Q24i*0,231+Q225i*0,503 \\
\hline Financial knowledge & Q28+Q29+Q30+Q31+Q32+Q33+Q34+Q35 \\
\hline Age & Age in years \\
\hline Income & Total monthly family income in reais \\
\hline Gender dummy & 0 = female; 1 = male \\
\hline Marital status dummy & 0 = single, widowed, separated; 1 = married \\
\hline Schooling dummy & $\begin{array}{l}0 \text { = did not study, elementary school, high school; } 1 \text { = higher } \\
\text { education or postgraduate }\end{array}$ \\
\hline Dependent dummy & 0 = has no dependents; 1 = has dependents \\
\hline
\end{tabular}

Source: Elaborated by the authors.

\section{ANALYSIS OF RESULTS}

Initially, we sought to analyze the participants' perception of FWB. This analysis involved two steps. First, the descriptive statistics of the two blocks of questions that make up the FWB measure are presented. Subsequently, the FWB level of the interviewees is calculated and presented using the methodology proposed by the CFPB (2015b). Figures 4.1 and 4.2 show the descriptive statistics of the questions on the FWB scale. 


\section{(Figure 4.1)}

DESCRIPTIVE STATISTICS OF THE FWB CONSTRUCT (PART 1), AVERAGES, CONFIDENCE INTERVAL, STANDARD DEVIATION AND PERCENTAGES

\begin{tabular}{|c|c|c|c|c|c|c|c|}
\hline \multirow{3}{*}{ Variables } & \multirow{3}{*}{$\begin{array}{l}\text { Average } \\
\text { (95\% conf. } \\
\text { interval) }\end{array}$} & \multirow{3}{*}{$\begin{array}{l}\text { Standard } \\
\text { deviation }\end{array}$} & \multicolumn{5}{|c|}{ Percentages } \\
\hline & & & Completely & $\begin{array}{l}\text { Very } \\
\text { well }\end{array}$ & Somewhat & $\begin{array}{l}\text { Very } \\
\text { little }\end{array}$ & $\begin{array}{l}\text { Not } \\
\text { at all }\end{array}$ \\
\hline & & & $(1)$ & (2) & (3) & (4) & (5) \\
\hline $\begin{array}{l}\text { 22. You could handle a large } \\
\text { unexpected expense.** }\end{array}$ & $\begin{array}{c}3.37 \\
(3.26-3.48)\end{array}$ & 1.35 & 11.6 & 15.3 & 26.4 & 17.6 & 29.1 \\
\hline $\begin{array}{l}\text { 23. You are securing your } \\
\text { financial future. }{ }^{\star \star}\end{array}$ & $\begin{array}{c}3.33 \\
(3.23-3.44)\end{array}$ & 1.26 & 9.3 & 14.8 & 33.9 & 17.1 & 24.8 \\
\hline $\begin{array}{l}\text { 24. Because of your } \\
\text { financial situation, you feel } \\
\text { that you will never have the } \\
\text { things you want in life. }\end{array}$ & $\begin{array}{c}3.91 \\
(3.80-4.02)\end{array}$ & 1.32 & 9.1 & 4.5 & 23.4 & 12.2 & 50.8 \\
\hline $\begin{array}{l}\text { 25.You can enjoy life } \\
\text { because of the way you are } \\
\text { managing your money. }{ }^{\star \star}\end{array}$ & $\begin{array}{c}2.38 \\
(2.29-2.47)\end{array}$ & 1.08 & 22.2 & 36.9 & 27.4 & 8.1 & 5.5 \\
\hline $\begin{array}{l}\text { 26. You are just surviving } \\
\text { financially. }\end{array}$ & $\begin{array}{c}3.15 \\
(3.02-3.29)\end{array}$ & 1.58 & 24.1 & 12.4 & 20.9 & 9.7 & 32.9 \\
\hline $\begin{array}{l}\text { 27. You are concerned that } \\
\text { the money you have or will } \\
\text { have saved may not be } \\
\text { enough. }\end{array}$ & $\begin{array}{c}2.71 \\
(2.59-2.84)\end{array}$ & 1.51 & 32.3 & 15.2 & 23.5 & 8.2 & 20.9 \\
\hline
\end{tabular}

${ }^{\star *}$ Inverted scales.

Most averages were around 3.0, revealing that respondents feel an intermediate level of FWB. The variable that indicates the greatest feeling of financial satisfaction was: "Because of your financial situation, you feel that you will never have the things you want in life," where $63 \%$ of respondents stated that "not at all" or "very little" of them feel that they will never have the things they want in life. The second variable that indicates a good level of FWB was: "You can enjoy life due to the way you are managing your money," in which the majority $(59.10 \%)$ stated that they enjoy it completely or very well. These variables are in line with what was highlighted by the CFPB (2015a) as elements inherent to the FWB, such as "being on the path to achieve imposed goals" and being "able to make choices that allow them to enjoy life." 
Intermediate perceptions were found in the variables "You could handle a large unexpected expense" and "You are guaranteeing your financial future""; the two variables being inverted. It was noticed that a large part of the individuals responded "not at all" or "a little," indicating that the individuals do not reach a higher FWB due to the difficulty in accumulating resources throughout their lives to prevent unexpected expenses and guarantee the future, leading them to worries and feelings of insecurity about unforeseen events. Thus, individuals lack goals, such as saving a monthly amount of resources. It is understood that this is not an easy task, especially for families with lower income levels. However, saving as little as possible tends to have a positive impact on the FWB.

The variable "You are just surviving financially" also had an intermediate average. On this variable, we revisited the aspect mentioned by authors such as Chan et al. (2012), Malone et al. (2010) and Norvilitis et al. (2003): the notion of FWB addresses concerns about the present and the meeting of the momentary needs, as well as one's future financial situation.

The most unfavorable perception of FWB was demonstrated in the variable "Are you concerned that the money you have or will have saved may not be enough?", in which $32.30 \%$ reported being completely concerned, $15.20 \%$ very worried and $23.50 \%$ a little worried. This result reveals that PMCMV beneficiaries believe they would need to save more in order to have full financial security in the future. According to the CFPB (2015a), saving resources monthly for retirement is an inherent element of well-being but one not observed in the respondents.

Continuing the analysis of FWB, Figure 4.2 presents the descriptive statistics of the second part of the construct.

\section{(Figure 4.2)}

DESCRIPTIVE STATISTICS OF THE FWB CONSTRUCT (PART 2), AVERAGES, CONFIDENCE INTERVALS, STANDARD DEVIATION AND PERCENTAGES

\begin{tabular}{|c|c|c|c|c|c|c|c|}
\hline \multirow{3}{*}{ Variables } & \multirow{3}{*}{$\begin{array}{l}\text { Average } \\
\text { (95\% conf. } \\
\text { interval) }\end{array}$} & \multirow{3}{*}{$\begin{array}{l}\text { Standard } \\
\text { deviation }\end{array}$} & \multicolumn{5}{|c|}{ Percentages } \\
\hline & & & Always & Often & Sometimes & Rarely & Never \\
\hline & & & (1) & (2) & (3) & (4) & (5) \\
\hline $\begin{array}{l}\text { 28. Giving a wedding, } \\
\text { birthday or other gift } \\
\text { would put your month's } \\
\text { finances in trouble. }\end{array}$ & $\begin{array}{c}3.20 \\
(3.07-3.31)\end{array}$ & 1.47 & 21.60 & 8.00 & 26.40 & 17.00 & 27.00 \\
\hline
\end{tabular}




\section{(Figure 4.2 (conclusion))}

DESCRIPTIVE STATISTICS OF THE FWB CONSTRUCT (PART 2), AVERAGES, CONFIDENCE INTERVALS, STANDARD DEVIATION AND PERCENTAGES

\begin{tabular}{|c|c|c|c|c|c|c|c|}
\hline \multirow{3}{*}{ Variables } & \multirow{3}{*}{$\begin{array}{l}\text { Average } \\
\text { (95\% conf. } \\
\text { interval) }\end{array}$} & \multirow{3}{*}{$\begin{array}{l}\text { Standard } \\
\text { deviation }\end{array}$} & \multicolumn{5}{|c|}{ Percentages } \\
\hline & & & Always & Often & Sometimes & Rarely & Never \\
\hline & & & (1) & (2) & (3) & (4) & (5) \\
\hline $\begin{array}{l}\text { 29.You have money left } \\
\text { over at the end of the } \\
\text { month. }{ }^{\star \star}\end{array}$ & $\begin{array}{c}3.03 \\
(2.93-3.14)\end{array}$ & 1.29 & 16.80 & 14.00 & 35.40 & 16.60 & 17.20 \\
\hline $\begin{array}{l}\text { 30. You are not up to } \\
\text { date with your finances. }\end{array}$ & $\begin{array}{c}3.99 \\
(3.88-4.09)\end{array}$ & 1.27 & 6.80 & 8.20 & 15.90 & 17.70 & 51.30 \\
\hline $\begin{array}{l}\text { 31. Your finances control } \\
\text { your life. }\end{array}$ & $\begin{array}{c}2.93 \\
(2.81-3.06)\end{array}$ & 1.48 & 24.00 & 15.70 & 28.10 & 7.50 & 24.70 \\
\hline
\end{tabular}

** Inverted scales.

It is noticed that the variable with the highest average is the one that indicates that individuals are up to date with their finances. This result is very positive, as having control over finances and being able to pay bills on time brings financial security and significantly increases the personal FWB (CFPB, 2015a).

It is observed that the other variables showed an intermediate level of FWB, with the average around three. As for the variable referring to having money left over at the end of the month, attention is paid to the highest percentage in the "sometimes" alternative (35.40\%), and only $16.80 \%$ always has money left over at the end of the month. This finding is worrying, in the sense that if unexpected expenses and emergencies occur, the financial situation of these families can suffer damage, negatively impacting the FWB. However, in order to make it possible to have money left over at the end of the month, for both low-income and high-income individuals, effective financial planning and money control are necessary, as the lack of financial management can lead to financial dissatisfaction (Kim et al., 2003).

The variable "Your finances control your life" presented the worst rating on the FWB scale in this block, which refers to the situation that money and the constant commitment to the bills end up controlling people's lives, which becomes a worrying factor given that finances and their proper use are important aspects for individuals. According to the CFPB (2015a), to 
achieve the FWB, the individual needs to have control over finances, financial reserve and also enjoy life, that is, if he plans financially, so that it is possible to take a vacation, enjoy a meal outside home and, in some moments, work less and spend more time with the family.

In the next stage, based on the procedure proposed by the CFPB (2015b), the level of FWB of individuals was computed. The histogram (Figure 4.3) shows the distribution on the scale.

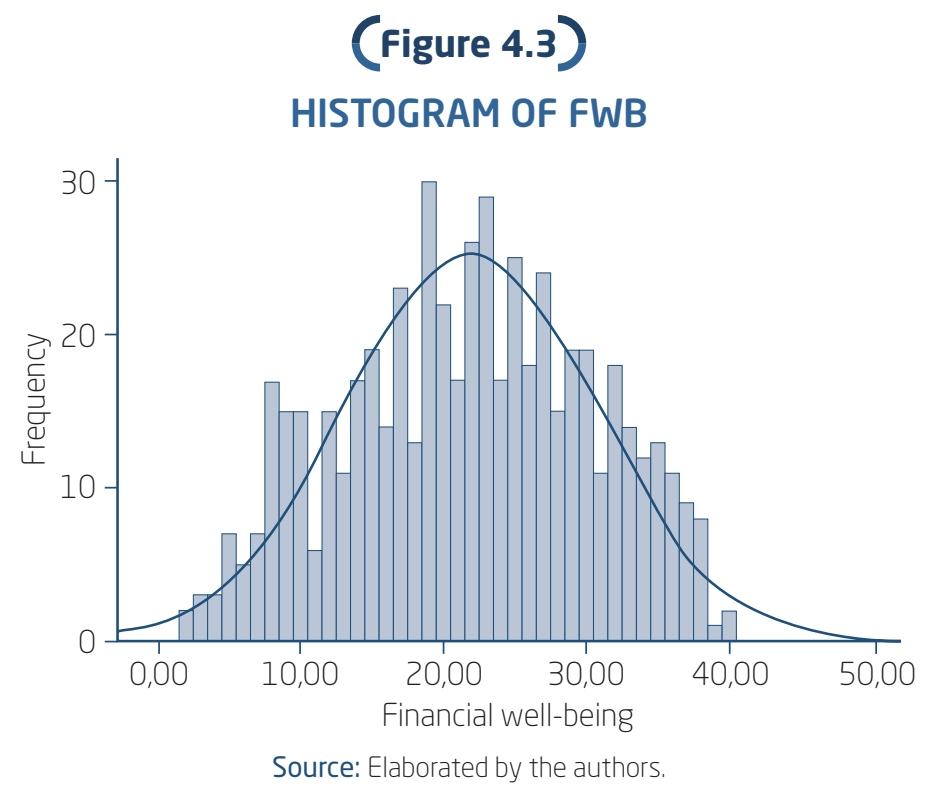

The average level of FWB, on a scale ranging from 0 to 40, was 22 points, with a standard deviation of 8.72. It is observed that the distribution is slightly asymmetric, with more beneficiaries at very low levels than at high levels. The Kolmogorov-Smirnov normality test accepted the null hypothesis (value 1.064; sig 0.207), indicating that the FWB scale has a normal distribution.

In order to verify if there are differences in the means of the level of FWB when considering the PMCMV financing ranges and six socioeconomic and demographic variables (gender, marital status, dependents, education, occupation and monthly family income), we conducted $t$ and ANOVA tests. The presentation of the significance of the tests is shown in Figure 4.4. In Figure 4.5, we present the results of the post hoc tests. 


\section{(Figure 4.4)}

TESTS OF DIFFERENCE OF MEAN OF FWB CONSIDERING THE FINANCING RANGE AND SOCIOECONOMIC AND DEMOGRAPHIC VARIABLES (P-VALUES IN PARENTHESES)

\begin{tabular}{lcccc}
\hline \multirow{2}{*}{ Variables } & Financial wellbeing & \multirow{2}{*}{ Variables } & & Financial wellbeing \\
\cline { 2 - 3 } & Value (significance) & & Value (significance) \\
\hline Financing range $^{1}$ & $-9.279(0.000)$ & Marital status $^{2}$ & $2.977(0.031)$ \\
\hline Gender $^{1}$ & $5.007(0.000)$ & Education $^{2}$ & \\
\hline Has dependents $^{1}$ & $5.950(0.000)$ & Occupation $^{2}$ & & $5.386(0.000)$ \\
\hline & & Family income $^{2}$ & $47.351(0.000)$ \\
\hline
\end{tabular}

Groups division: financing ranges: 1, 2 and 3. Gender. male and female; Has dependents: yes, no. Marital status: married, single, widowed, separated. Education: never studied, elementary school from 1st to 4th grade, elementary school from 5th to 9th grade, high school, technical course, college (higher education), specialization or MBA, masters/doctorate/postdoctorate. Occupation: salaried with a formal contract, salaried without a formal contract, civil servant, self-employed, businessman, freelancer, housewife, retired, student, unemployed (looking for a job), unemployed (no looking for a job), other. Family income: up to $R \$ 1,600.00$, from $R \$ 1,600.01$ to $R \$ 3,275.00$, from $R \$ 3,275.01$ to $R \$ 5,000.00$, above $R \$ 5,000.00$.

${ }^{1} t$ test; ${ }^{2}$ ANOVA.

Source: Elaborated by the authors.

\section{(Figure 4.5)}

TUKEY/GAMES-HOWELL HDS POST HOC TEST, DIFFERENCE IN MEAN AND SIGNIFICANCE FOR EACH AGE, EDUCATION, OCCUPATION AND INCOME LEVEL THAT SHOWED A SIGNIFICANT DIFFERENCE IN THE FWB FACTOR

\begin{tabular}{|c|c|c|c|c|}
\hline & \multicolumn{2}{|c|}{ Variables } & \multirow{2}{*}{$\begin{array}{c}\text { Difference } \\
\text { in means }\end{array}$} & \multirow{2}{*}{$\begin{array}{l}\text { Sig. } \\
0.002\end{array}$} \\
\hline \multirow{8}{*}{ Education $^{2}$} & High school & Elementary school 1st to 4th grade & & \\
\hline & \multirow{2}{*}{ Technical Course } & Elementary school 1st to 4th grade & 6.183 & 0.002 \\
\hline & & Elementary school 5th to 9th grade & 5.315 & 0.034 \\
\hline & \multirow{3}{*}{ College } & Elementary school 1st to 4th grade & 8.469 & 0.000 \\
\hline & & Elementary school 5th to 9th grade & 7.601 & 0.000 \\
\hline & & High school & 3.937 & 0.000 \\
\hline & \multirow{2}{*}{$\begin{array}{l}\text { Masters/doctorate/ } \\
\text { postdoctorate }\end{array}$} & Elementary School 1st to 4th grade & 9.341 & 0.009 \\
\hline & & Elementary School 5th to 9th grade & 8.473 & 0.024 \\
\hline
\end{tabular}




\section{(Figure 4.5 (conclusion))}

TUKEY/GAMES-HOWELL HDS POST HOC TEST, DIFFERENCE IN MEAN AND SIGNIFICANCE FOR EACH AGE, EDUCATION, OCCUPATION AND INCOME LEVEL THAT SHOWED A SIGNIFICANT DIFFERENCE IN THE FWB FACTOR

\begin{tabular}{|c|c|c|c|c|}
\hline & Varic & bles & $\begin{array}{l}\text { Difference } \\
\text { in means }\end{array}$ & Sig. \\
\hline & Salaried with a formal & Freelancer & 7.745 & 0.004 \\
\hline & contract & Housewife & 5.316 & 0.023 \\
\hline & & Freelancer & 9.654 & 0.001 \\
\hline & & Housewife & 7.226 & 0.004 \\
\hline Ocrunztion 1 & Civil servant & Unemployed (looking for a job). & 7.245 & 0.031 \\
\hline Secupationi & & Unemployed (not looking for a job). & 9.404 & 0.023 \\
\hline & & Other & 7.363 & 0.018 \\
\hline & & Free-lancer & 9.170 & 0.002 \\
\hline & $\begin{array}{l}\text { Regular } \\
\text { self-emploved }\end{array}$ & Housewife & 6.741 & 0.010 \\
\hline & & Other & 6.878 & 0.035 \\
\hline & $\begin{array}{l}\text { From } R \$ 1,600.01 \\
\text { to } R \$ 3,275.00\end{array}$ & Up to $\mathrm{R} \$ 1,600.00$ & 5.093 & 0.000 \\
\hline & From $R \$ 3,275.01$ & Up to $\mathrm{R} \$ 1,600.00$ & 8.235 & 0.000 \\
\hline Income $e^{2}$ & to $R \$ 5,000.00$ & From $\mathrm{R} \$ 1,600.01$ to $\mathrm{R} \$ 3,275.00$ & 3.143 & 0.001 \\
\hline & & Up to $\mathrm{R} \$ 1,600.00$ & 13.821 & 0.000 \\
\hline & Above $R \$ 5,000.00$ & From $R \$ 1,600.01$ to $R \$ 3,275.00$ & 8.729 & 0.000 \\
\hline & & From $R \$ 3,275.01$ to $R \$ 5,000.00$ & 5.586 & 0.000 \\
\hline
\end{tabular}

${ }^{1}$ Tukey's post hoc HDS test; ${ }^{2}$ Games-Howell post hoc test.

Source: Elaborated by the authors.

Significant mean differences were found for all variables studied. The results indicate that individuals who have financing in the PMCMV of groups 2 and 3 (average 23,870), are male (average 24,332) and who do not have dependents (average 24,046), exhibit greater FWB.

In the influence of the gender variable, Leach, Hayhoe, and Turner (1999) report that women normally experience greater adversity and stress when it comes to their finances, which ends up affecting their FWB. Shim 
et al. (2009) and Gutter and Copur (2011) also found that men have higher levels of FWB than women. As for the variable "number of dependents", the results of the present study are in accordance with what has already been demonstrated by Penn (2007) and Kunkel (2014), that is, that the number of children or dependents at home constitutes a factor that negatively influences FWB.

Regarding the variable "level of education", it was found that respondents with the highest level of education also had the highest average scores. Individuals with graduate degrees (average score 26.50) and those with higher education (average 25.63) stand out. It is also worth mentioning the low level of FWB of those who have never studied (average 15.429) and the high discrepancy for individuals with a higher level of education. The greatest differences in means with statistical significance were found between those with graduate degrees (master's/doctorate/postdoctorate) and those who attended elementary school from the 1 st to the 4 th $(9,341)$, and the 5 th to the 9 th year $(8,473)$, followed by the difference between those in the graduation group and those who completed the 4th grade of elementary school $(8,469)$. The results obtained in this study are, thus, in line with those of Lown and Ju (1992) and Diniz et al. (2014, 2015), who found that those with a higher educational level tend to be more financially satisfied. Penn (2007) also observed that individuals with university degrees are more likely to get safer jobs and higher wages, factors that positively influence the FWB.

For the "occupation" variable, civil servants had the highest average FWB $(24,655)$, corroborating the study by Diniz et al. (2015). Regular freelancers and entrepreneurs also had high averages of FWB (24.170 and 24.067, respectively). On the other hand, freelancers and the unemployed had the lowest averages (15.000 and 15.250, respectively).

Through post hoc testing, it was found that the greatest differences, on average, occurred between civil servants and freelancers (9.654) and between civil servants and the unemployed (those that are not seeking employment) (9.404). It appears, from these differences, that stability is a very important point in determining FWB and that lacking a certain income each month negatively affects the perception of financial satisfaction. According to Plagnol (2011), being unemployed - which may include individuals who do not have a fixed job - refers to the impossibility of accumulating savings and to a commonly observed scenario of anxiety related to the financial situation.

For the "income" variable, it was found that people with an income above $\mathrm{R} \$ 5,000.00$ are the most likely to have a higher level of FWB (average score of 29.929). Furthermore, it can be said that the increase in income is accompanied by greater satisfaction with finances, with the greatest 
difference in means (13.821) occurring between the lowest and the highest income group. Delafrooz and Paim (2011), Gutter and Copur (2011), Kunkel (2014) and Diniz et al. (2014) also found that income has a significant coefficient and a positive correlation with FWB. For Penn (2007), an increase in family income is directly related to the self-perception of financial security. Vlaev and Elliott (2014) obtained a similar result when investigating FWB in young workers and families in the UK. These authors found that about $37 \%$ of respondents felt they had less than an excellent level of FWB, given an insufficient income.

In our study, in order to adequately classify respondents across various income levels, we applied the procedure suggested by the CFPB (2015b), in which the FWB is stratified into six levels. The classification table considers three main points: 1 . the score obtained in the FWB indicator; 2 . age, itself divided into two categories (from 18 to 61 years, 62 and above); 3. the manner in which the instrument is administered (either self- or by another, as is the case in this study). Thus, using these three criteria, the classification shown in Figure 4.6 was obtained.

(Figure 4.6)

LEVEL OF FWB OF RESPONDENTS, ACCORDING TO THE CFPB CLASSIFICATION

\begin{tabular}{|c|c|c|c|c|c|c|}
\hline \multirow{3}{*}{$\begin{array}{l}\text { Financial } \\
\text { well-being } \\
\text { level }\end{array}$} & \multirow{3}{*}{ Score } & \multicolumn{4}{|c|}{ Age } & \multirow{3}{*}{ Chi-square } \\
\hline & & \multicolumn{2}{|c|}{18 to 61} & \multicolumn{2}{|c|}{62 or more } & \\
\hline & & Frequency & Percentage & Frequency & Percentage & \\
\hline Very low & $0-29$ & 8 & 1.6 & 0 & 0 & \\
\hline Low & 30-37 & 34 & 6.7 & 2 & 4.8 & \\
\hline Medium-low & $38-49$ & 134 & 26.3 & 16 & 38.1 & \\
\hline Medium-high & $50-57$ & 131 & 25.7 & 12 & 28.6 & $\begin{array}{c}\text { Value } 4.5 / 6 \\
\text { Sig. } 0.470\end{array}$ \\
\hline High & $58-67$ & 121 & 23.7 & 6 & 14.3 & \\
\hline Very high & $68-100$ & 82 & 16.1 & 6 & 14.3 & \\
\hline Total & & 510 & 100.0 & 42 & 100.0 & \\
\hline
\end{tabular}

Source: Elaborated by the authors.

It can be noted that, in this classification, the FWB level is re-scaled to a scale ranging from zero to 100 , taking into account the three criteria. Only 42 individuals are 62 years old or more and, in this group, the majority 
$(66.7 \%)$ is in the medium-low or medium-high level of FWB. In the most representative group (from 18 to 61 years old), most are also at these levels (52\%), but a significant portion has a high $(23.7 \%)$ and very high $(16.1 \%)$ FWB score. Whereas, at the two lowest levels, only $8.3 \%$ of respondents were classified. Such results indicate that, despite the compromise of the income for the financing of their houses, the beneficiaries, in general, present average to high levels of FWB. The chi-square test indicates that there is no association between the FWB level and the two age categories. These results go against the evidence that older individuals would have higher levels of FWB (Sumarwan,1990; Xiao, Sorhaindo, \& Garman, 2006; Plagnol, 2011; Kunkel, 2014).

In the next step, we sought to confirm the constructs of financial attitude and financial behavior from the confirmatory factor analysis. Figure 4.7 presents the adjustment indexes of the initial and final models.

(Figure 4.7)

CONSTRUCT ADJUSTMENT INDEXES OF FINANCIAL BEHAVIOR AND FINANCIAL ATTITUDE IN THE INITIAL AND FINAL MODELS

\begin{tabular}{lcccc}
\hline \multirow{2}{*}{ Adjustment indices } & \multicolumn{2}{c}{ Financial behavior } & \multicolumn{2}{c}{ Financial attitude } \\
\cline { 2 - 5 } & $\begin{array}{c}\text { Initial } \\
\text { model }\end{array}$ & $\begin{array}{c}\text { Final } \\
\text { model }\end{array}$ & $\begin{array}{c}\text { Initial } \\
\text { model }\end{array}$ & $\begin{array}{c}\text { Final } \\
\text { model }\end{array}$ \\
\hline Chi-square (value) & 244.134 & 4.388 & 245.703 & 2.306 \\
\hline Chi-square (probability) & 0 & 0.356 & 0 & 0.129 \\
\hline Degrees of freedom & 27 & 4 & 20 & 1 \\
\hline Chi-square/degrees of freedom & 9.042 & 1.097 & 12.285 & 2.306 \\
\hline Goodness of fit (GFI) & 0.914 & 0.997 & 0.894 & 0.997 \\
\hline Comparative fit index (CFI) & 0.907 & 1 & 0.521 & 0.991 \\
\hline Normed fit index (NFI) & 0.897 & 0.998 & 0.508 & 0.984 \\
\hline Tucker-Lewis index (TLI) & 0.876 & 1 & 0.330 & 0.973 \\
\hline Root mean square residual (RMR) & 0.174 & 0.025 & 0.154 & 0.048 \\
\hline R. M. s error of approximation (RMSEA) & 0.12 & 0.013 & 0.142 & 0.048 \\
\hline Reliability index & 0.787 & 0.870 & 0.567 & 0.584 \\
\hline Cronbach's alpha & 0.798 & 0.859 & 0.540 & 0.550 \\
\hline
\end{tabular}


It is possible to notice that the initial models proved to be inadequate. Thus, from the verification of the adjustment indexes, the exclusion of nonsignificant questions was used as an improvement criterion, followed by the gradual exclusion of questions that did not present satisfactory coefficients. For the financial behavior construct, questions with their respective coefficients were successively excluded: 27 (0.209), 21 (0.289), 26 (0.312), 20 (0.479 and $22(0.486)$. A positive correlation was also inserted between the errors of the variables "You start saving more when you receive a salary increase" and "You make a reserve of money that you receive monthly for a future need." Question 12 was removed for the financial attitude construct, as it had a non-significant coefficient and variables 15 (0.247), and questions $11(0.288)$ and $13(0.327)$ for having low coefficients. After these adjustments, all models showed satisfactory adjustment indexes, except the Cronbach's alpha of the financial attitude construct, which was below the desirable level.

Finally, the linear multiple regression model is estimated in order to analyze the influence of the dimensions of financial literacy on FWB (Figure 4.8).

\section{(Figure 4.8)}

RESULTS OF THE REGRESSION MODEL FOR FWB

\begin{tabular}{lcccc}
\hline \multicolumn{1}{c}{ Variables } & $\begin{array}{c}\text { Standardized } \\
\text { coefficients }\end{array}$ & t-stat & Sig. & VIF \\
\hline Financial knowledge & 0.113 & 3.375 & 0.001 & 1.287 \\
\hline Financial behavior & 0.435 & 12.948 & 0.000 & 1.286 \\
\hline Financial atitude & 0.245 & 7.347 & 0.000 & 1.264 \\
\hline Age & 0.036 & 1.154 & 0.249 & 1.129 \\
\hline Income & 0.200 & 5.627 & 0.000 & 1.441 \\
\hline Gender dummy & 0.005 & 0.158 & 0.874 & 1.139 \\
\hline Dummy marital status & 0.005 & 0.161 & 0.872 & 1.129 \\
\hline Schooling dummy & 0.029 & 0.844 & 0.399 & 1.325 \\
\hline Dependent dummy & -0.081 & -2.565 & 0.011 & 1.152 \\
\hline$R^{2}$ & 0.548 & & & \\
\hline Adjusted $R^{2}$ & 0.540 & & & \\
\hline F(sig) & $69.457(0.000)$ & & & \\
\hline Kolmogorov Smirnov Z (sig) & $0.619(0.838)$ & & & \\
\hline Pesaran-Pesaran & $-0.473(0.637)$ & & & \\
\hline & & & & \\
\hline
\end{tabular}


The estimation by ordinary least squares is adequate, since the model meets the assumptions of the absence of problems related to multicollinearity, heteroscedasticity and non-normality. The adjusted determination coefficient indicates that $58 \%$ of the variation in the perception of FWB can be explained by the variables included in the model.

The three dimensions of financial literacy showed significant and positive coefficients. Among the three dimensions, the one with the greatest impact, with a 0.435 coefficient, is financial behavior, confirming that better financial behaviors imply a significant increase in FWB. Then there is the financial attitude, in which for each increase of a unit on the financial attitude scale, there is an increase of 0.245 in the FWB. And finally, financial knowledge, with a coefficient of 0.113 , that is, an increase of one point in the level of financial knowledge implies an increase of 0.113 in the level of FWB. Together, the three dimensions corroborate with the argument that it is not enough for the individual to have the knowledge, but it is also necessary for the individual to show appropriate attitudes and behaviors to achieve a higher level of well-being. Such results are in line with the evidence that points out that financial behaviors (Delafrooz \& Paim, 2011; Mokhtar \& Husniyah, 2017), financial attitudes (Joo, 2008) and financial knowledge (Joo \& Grable, 2004; Robb \& Woodyard, 2011; Falahati et al., 2012; BCB, 2017) are determinants of FWB.

Another determinant is income (with a coefficient of 0.200), indicating that increases in income positively influence the level of FWB, which corroborates with previous studies that indicated that individuals with higher income have higher levels of FWB (Delafrooz \& Paim, 2011; Gutter \& Copur, 2011; Fraga, Vieira, Ceretta, \& Paraboni, 2016, among others). On the other hand, the age variable was not significant $(p=.249)$, contradicting (Sumarwan, 1990; Xiao et al., 2006; Plagnol, 2011; Kunkel, 2014) and suggesting that older individuals have higher levels of FWB.

Regarding the dummy variables, only "having dependents" was significant $(p=.011)$, indicating that having dependents reduces the level of FWB. This suggests that being financially responsible for others reduces the perception of FWB. This result is consistent with those already obtained by Penn (2007) and Kunkel (2014). For marital status and education, the literature still does not have a consensus; the absence of influence seems to be another possibility.

Therefore, the results of the model confirm the hypothesis raised in the study, that financial literacy acts as a precedent for FWB. The three dimensions contribute positively to FWB, corroborating the argument that an 
increase in the individual level of financial literacy is essential for them to reach higher levels of FWB.

\section{FINAL REMARKS}

Measuring FWB is a relevant topic, as financial markets are increasingly complex and, with that, offer individuals a wide variety of investment options, loans, and access to credit. However, many individuals are unaware of the risks and high rates of some financial instruments, which can lead to lower levels of FWB (Schmeiser \& Hogarth, 2013).

This situation may become even more critical, due to the country's current financial situation, in which the percentages of indebtedness and defaults in April 2019 totaled 62.7\% (percentage of indebtedness), 23.9\% (with overdue accounts) and $9.5 \%$ (will not be able to pay; Confederação Nacional do Comércio de Bens, Serviços e Turismo, 2019). And with the increase in unemployment, there is a disincentive to saving. This can lead to a lack of resources for essential features of financial security: maintaining a standard of living and FWB. One should also consider the fact that the FWB is a broad aspect, highly interrelated with other aspects of life (suggesting, therefore, its relationship with general well-being, happiness, satisfaction and quality of life; Gutter \& Copur, 2011).

Thus, this work sought to measure the level of FWB of the beneficiaries of the PMCMV and to test the hypothesis that financial literacy is an antecedent of FWB. The results indicated that the majority of the program participants have average levels of FWB. Thus, the hypothesis that financial literacy is an antecedent of FWB was confirmed, since the three dimensions of literacy had a positive impact on FWB. The typical profile for respondents with higher levels of FWB are men, young people, married, with higher education and higher income. Such results indicate that the use of national strategies designed to increase the population's level of financial literacy must have a direct impact on the level of FWB. In doing so, it corroborates the argument already promoted by some international organizations (e.g. OECD and CFPB), that a measure of success in financial literacy is the FWB. It is also emphasized that, for strategies to be more effective, they need to focus not only on expanding financial knowledge but also using methodologies and content that benefit changes in attitude and financial behaviors.

Despite the limitations inherent in the study, such as the choice of a specific sample group, it is understood that the CFPB scale (2015b) presents 
itself as a potential measure of FWB assessment for the Brazilian context. However, there is still a need for several studies for its validation. Included among these are: its application in different population groups; the use of structural equation modeling to validate the two dimensions proposed by the scale; the application of the Item Response Theory to assess the behavior of questions within the scale and its application (along with other behavioral constructs), in order to assess their discriminating validity and/or confirm their relationships with other factors, such as numeracy, personality traits, and use of other debt instruments (e.g. credit cards).

\section{BEM-ESTAR FINANCEIRO DOS BENEFICIÁRIOS DO MINHA CASA MINHA VIDA: PERCEPÇÃO E ANTECEDENTES}

\section{RESUMO}

Objetivo: Este artigo tem dois objetivos principais: 1. mensurar o nível de bem-estar financeiro (BEF) dos beneficiários do Programa Minha Casa Minha Vida (PMCMV) e 2. testar a hipótese de que a alfabetização financeira é um antecedente do BEF.

Originalidade/valor: Considerando que ainda não há uma definição e uma medida universalmente aceitas para o BEF (Brüggen, Hogreve, Holmlund, Kabadayi, \& Löfgren, 2017), este estudo busca aplicar a metodologia proposta pelo Consumer Financial Protection Bureau (CFPB) no Brasil, uma vez que as tentativas anteriores de aplicação de outras escalas demonstraram uma grande instabilidade. E ainda é testada a hipótese de que a alfabetização financeira é um antecedente do BEF. Design/metodologia/abordagem: Para mensurar, o BEF utilizou-se a escala desenvolvida pelo CFPB. A alfabetização financeira foi construída a partir das três dimensões propostas pela Organisation for Economic Co-operation and Development (OECD), a saber: comportamento, atitude e conhecimento financeiros. O instrumento foi aplicado em 561 beneficiários das três faixas de financiamento do PMCMV. Utilizaram-se para análise técnicas de estatística descritiva, análise fatorial confirmatória e regressão linear múltipla.

Resultados: Os resultados indicaram que a maioria dos beneficiários do programa apresenta níveis médio baixo e médio alto de BEF. A hipótese de que a alfabetização financeira é um antecedente do BEF foi confirmada, 
e as três dimensões impactaram positivamente. O nível de renda também exerce impacto positivo, ao passo que o fato de possuir dependentes exerce influência negativa no nível de BEF. A escala de BEF proposta pelo CFPB parece adequada ao contexto brasileiro. O avanço nas estratégias nacionais de alfabetização financeira tende a ampliar o BEF dos beneficiários do PMCMV.

\section{PALAVRAS-CHAVE}

Bem-estar financeiro. Programa Minha Casa Minha Vida. Alfabetização financeira. Proteção financeira. Escalas de bem-estar.

\section{REFERENCES}

Adam, A. M., Frimpong, S., \& Boadu, M. O. (2017). Financial literacy and financial planning: Implication for financial well-being of retirees. Business and Economic Horizons, 13(2), 224-236. doi:10.15208/beh.2017.17

Aggarwal, S. (2014). Developing an index for measuring financial well-being in a geography. IFMR Finance Foundation. Retrieved from https://www. dvara.com/blog/2011/02/14/developing-an-index-for-measuring-financialwell-being-in-a-geography/Alessie, R., Van Rooij, M., \& Lusardi, A. (2011). Financial literacy and retirement preparation in the Netherlands. Journal of Pension Economics and Finance, 10(4), 527-545. doi:10.1017/S1474747211 000461

Arber, S., Fenn, K., \& Meadows, R. (2014). Subjective financial well-being, income and heal thin equalities in mid and later life in Britain. Social Science $\mathcal{E}$ Medicine, 100, 12-20. doi: 10.1016/j.socscimed.2013.10.016

Banco Central do Brasil (2017). Série Cidadania Financeira no 5 - Competências em educação financeira. Retrieved from https://www.bcb.gov. br/nor/relincfin/serie_cidadania_financeira_pesquisa_infe_br_\%200443_ 2017.pdf

Brasil (2010). Decreto $\mathrm{n}^{\circ} 7397$, de 22 de dezembro de 2010. Retrieved from http://www.planalto.gov.br/ccivil_03/_ato2007-2010/2010/decreto/d73 97.htm

Brasil (2018). Base Nacional Comum Curricular: Educação é a base. Retrieved from http://basenacionalcomum.mec.gov.br/wp-content/uploads/2018/ 04/BNCC_Ensino Medio_embaixa_site.pdf 
Brüggen, E. C., Hogreve, J., Holmlund, M., Kabadayi, S., \& Löfgren, M. (2017). Financial well-being: A conceptualization and research agenda. Journal of Business Research, 79, 228-237. doi:10.1016/j.jbusres.2017.03.013

Caixa Econômica Federal (2015a). Manual do Programa Minha Casa Minha Vida - Entidades Recursos FDS. Retrieved from http://www.caixa.gov. br/Downloads/habitacao-minha-casa-minha-vida/MANUAL_MCMV ENTIDADES.pdf.

Caixa Econômica Federal (2015b). Carta de crédito FGTS imóvel na planta associativo. Retrieved from http://www.caixa.gov.br/Downloads/habitacaodocumentos-gerais/Carta_de_Credito_FGTS_E_OUTROS.pdf

Campara, J. P., Vieira, K. M., \& Potrich, A. C. G. (2017). Satisfação global de vida e bem-estar financeiro: Desvendando a percepção de beneficiários do Programa Bolsa Família. Revista de Administração Pública, 51 (2), 182-200. doi:10.1590/0034-7612156168

Chan, K. Y. K., Chan, S. F., \& Chau, A. W. L. (2012). Financial knowledge and aptitudes: Impacts on college students' financial well-being. College Student Journal, 46(1), 114-133.

Chan, S., Omar, S., \& Yong, W. (2018). Financial well-being among Malaysian manufacturing employees. Management Science Letters, 8(6), 691-698. doi:10.5267/j.msl.2018.4.020

Confederação Nacional do Comércio de Bens, Serviços e Turismo (2019). Pesquisa Nacional de Endividamento e Inadimplência do Consumidor (PEIC) - abril 2019. Retrieved from http://cnc.org.br/sites/default/files/ arquivos/analise_peic_abril_2019.pdf

Consumer Financial Protection Bureau (2015a). Financial well-being: The goal of financial education. Washington, DC: CFPB. Retrieved from http://files. consumerfinance.gov/f/201501_cfpb_report_financial-well-being.pdf

Consumer Financial Protection Bureau (2015b). Measuring financial wellbeing: A guide to using the CFPB financial well-being scale. Washington, DC: CFPB. Retrieved from https://files.consumerfinance.gov/f/201512_cfpb_ financial-well-being-user-guide-scale.pdf

Delafrooz, N., \& Paim, L. H. (2011). Determinants of financial wellness among Malaysia workers. African Journal of Business Management, 5(24), 10.092-10.100. doi: 10.5897/AJBM10.1267

Delavande, A., Rohwedder, S., \& Willis, R. J. (2008). Retirement planning and the role of financial literacy and cognition [Working Paper $\mathrm{N}^{\circ} 190$ ]. Michigan Retirement Research Center Michigan. 
Diniz, A. P. C., Vieira, K. M., Potrich, A. C. G., \& Campara, J. P. (2014). Influência das variáveis socioeconômicas e demográficas no bem-estar financeiro: Um estudo do comportamento maranhense. Revista Uniabeu, 7(17), 218-234.

Diniz, A. P. C., Vieira, K. M., Potrich, A. C. G., \& Campara, J. P. (2015). Bem-estar financeiro: Uma análise multifatorial do comportamento maranhense. Estudos do CEPE, 42, 186-202. doi:10.17058/cepe.v0i42.6317

Falahati, L., Sabri, M. F., \& Paim, L. H. (2012). Assessment a model of financial satisfaction predictors: Examining the mediate effect of financial behaviour and financial strain. World Applied Sciences Journal, 20(2), 190-197. doi:10.5829/idosi.wasj.2012.20.02.1832

Fraga, L. S., Vieira, K. M., Ceretta, P. S., \& Paraboni, A. L. (2016). Bem-estar financeiro: Uma análise sob a perspectiva da renda. Revista de Finanças Aplicadas, 7, 1-28.

Garman, E. T., Sorhaindo, B., Bailey, W., Kim, J., \& Xiao, J. (2004). Financially distressed credit counseling clients and the incharge financial distress/financial well-being scale. Proceedings of the Eastern Regional Family Economics and Resource Management Association Conference. Retrieved from https://pfeef.org/wp-content/uploads/2016/09/Financially-DistressedClients-and-the-Scale.pdf

Guo, L., Arnould, E. J., Gruen, T. W., \& Tang, C. (2013). Socializing to co-produce: Pathways to consumers' financial well-being. Journal of Service Research, 16(4), 549-563. doi:10.1177/1094670513483904

Gutter, M., \& Copur, Z. (2011). Financial behaviors and financial well-being of college students: Evidence from a national survey. Journal of Family and Economic, 32 (4), 699-714. doi:10.1007/s10834-011-9255-2

Hair, J. R., Black, W. C., Babin, B. J., \& Anderson, R. E. (2010). Multivariate Data Analyses (7th ed.). New Jersey: Pearson.

Hira, T. K., \& Mugenda, O. M. (1999). The relationships between self-worth and financial beliefs, behavior, and satisfaction. Journal of Family and Consumer Sciences, 91 (4), 76-82.

Hooper, D., Coughlan, J., \& Mullen, M. R. (2008). Structural equation modelling: Guidelines for determining model fit. The Electronic Journal of Business Research Methods, 6(1), 53-60.

Huston, S. J. (2010). Measuring financial literacy. The Journal of Consumer Affairs, 44(2), p. 296-316, 2010. doi:10.1111/j.1745-6606.2010.01170.x Joo, S. (2008). Personal financial wellness. In J. J. Xiao (Ed.), Handbook of consumer finance research (pp. 21-34). New York: Springer. 
Joo, S. H., \& Grable, J. E. (2004). An exploratory framework of the determinants of financial satisfaction. Journal of Family and Economic Issues, 25(1), 25-50. doi: 10.1023/B:JEEI.0000016722.37994.9f

Kahneman, D., \& Deaton, A. (2010). High income improves evaluation of life but not emotional well-being. Proceedings of the National Academy of Sciences of the United States of America, 107(38), 16489-16493. doi:10.1073/pnas. 1011492107

Kim, J., Garman, E. T., \& Sorhaindo, B. (2003) Relationships among credit counseling clients' financial well-being, financial behaviors, financial stressor events, and health. Journal of Financial Counseling and Planning, 14(2), 75-87.

Klapper, L., Lusardi, A., \& Panos, G. A. (2013). Financial literacy and its consequences: Evidence from Russia during the financial crisis. Journal of Banking \& Finance, 37(10), 3904-3923. doi:10.1016/j.jbankfin.2013.07.014

Kline, R. B. (2011). Principles and practice of structural equation modeling (3rd ed.). New York: The Guilford Press.

Kunkel, F. I. R. (2014). Causas e consequências da dívida no cartão de crédito: Uma análise multifatorial (Dissertação de mestrado, Universidade Federal de Santa Maria, Santa Maria, Brasil).

Kunkel, F. I. R., Vieira, K. M., \& Potrich, A. C. G. (2015). Causas e consequências da dívida no cartão de crédito: Uma análise multifatores. Revista de Administração, 50, 169-182. doi: 10.5700/rausp1192

Leach, L. J., Hayhoe, C. R., \& Turner, P. R. (1999). Factors affecting perceived economic well-being of college students: A gender perspective. Journal of Financial Counseling and Planning, 10(2), 11-24.

Lown, J. M., \& Ju, I. S. (1992). A model of credit use and financial satisfaction. Financial Counseling and Planning, 3, 105-125.

Malone, K., Stewart, S. D., Wilson, J., \& Korsching, P. F. (2010). Perceptions of financial well-being among American women in diverse families. Journal of Family and Economic Issues, 31 (1), 63-81. doi:10.1007/s10834-009-9176-5

Mende, M., \& Van Doorn, J. (2015). Coproduction of transformative services as a pathway to improved consumer well-being: Findings from a longitudinal study on financial counseling. Journal of Service Research, 18(3), 351-368. doi:10.1177/1094670514559001

Mokhtar, N., \& Husniyah, A. R. (2017). Determinants of financial wellbeing among public employees in Putrajaya, Malaysia. Pertanika Journal of Social Sciences \& Humanities, 25(3), 1241-1260. 
Mundy, S. (2011). Financial education programmes in schools: Analysis of selected current programmes and literature [Mimeo]. Paris: OECD.

National Financial Capability Study (2013). Financial capability in the United States - Report of Findings from the 2012 National Financial Capability Study. Financial Industry Regulatory Authority (FINRA) Investor Education Foundation. Retrieved from http://www.usfinancialcapability.org/ downloads/NFCS_2012_Report_Natl_Findings.pdf

Norvilitis, J. M., Szablicki, P. B., \& Wilson, S. D. (2003). Factors influencing levels of credit card debt in college students. Journal of Applied Social Psychology, 33(5), 935-947. doi: 10.1111/j.1559-1816.2003.tb01932.x

O’Neill, B., Sorhaindo, B., Xiao, J. J., \& Garman, E. T. (2005). Financially distressed consumers: Their financial practices, financial well-being, and health. Financial Counseling and Planning, 16(1), 73-87.

O’Neill, B., \& Xiao, J. (2012). Financial behaviors before and after the financial crisis: Evidence from an online survey. Financial Counseling and Planning, 23(1), 33-46. Organisation for Economic Co-operation and Development (2013a). Financial literacy and inclusion: Results of OECD/Infe survey across countries and by gender. Paris: OECD. Retrieved from http://www.oecd.org/ daf/fin/financialeducation/TrustFund2013_OECD_INFE_Fin_Lit_and_ Incl_SurveyResults_by_Country_and_Gender.pdf

Organisation for Economic Co-operation and Development (2013b). Women and financial education: Evidence, policy responses and guidance. Paris: OECD. doi:10.1787/9 789264202733-en

Organisation for Economic Co-operation and Development (2015). OECD/ Infe toolkit for measuring financial literacy and financial inclusion. Paris: OECD. Retrieved from http://www.oecd.org/daf/fin/financial-education/2015 OECD_INFE_Toolkit_Measuri ng_Financial_Literacy.pdf

Organisation for Economic Co-operation and Development (2018). PISA 2015: Results in focus. Paris: OECD. Retrieved from http://www.oecd.org/ pisa/pisa-2015-results-in-focus.pdf

Penn, D. A. (2007). Financial well-being in an urban area: An application of multiple imputation [Working Paper]. Department of Economics and Finance, Paris.

Plagnol, A. C. (2011). Financial satisfaction over the life course: The influence of assets and liabilities. Journal of Economic Psychology, 32(1), 45-64. doi:10.1016/j.joep.2010.10.006 
Prawitz, A., Garman, E. T., Sorhaindo, B., O’Neill, B., Kim, J., \& Drentea, P. (2006). Incharge financial distress/financial well-being scale: Development, administration, and score interpretation. Journal of Financial Counseling and Planning, 17(1), 34-50. doi:10.1037/t60365-000

Robb, C. A., \& Woodyard, A. S. (2011). Financial knowledge and best practice behavior. Journal of Financial Counselling and Planning, 22 (1), 60-70.

Santos, D. B., Mendes-Da-Silva, W., Flores, E., \& Norvilitis, J. (2016). Predictors of credit card use and perceived financial well-being in female college students: a Brazil-United States comparative study. International Journal of Consumer Studies, 40(2), 133-142. doi: 10.1111/ijcs.12234

Schmeiser, M., \& Hogarth, J. (2013). Good advice, good outcomes? How financial advice-seeking relates to self-perceived financial well-being. In Social Science Research Network. [Working Paper]. Retrieved from https://papers.ssrn.com/sol3/papers.cfm?abstract_id=2261707

Shim, S., Xiao, J. J., Barber, B. L., \& Lyons, A. C. (2009). Pathways to life success: A conceptual model of financial well-being for young adults. Journal of Applied Developmental Psychology, 30, 708-723. doi:10.1016/j.appdev. 2009.02.003

Shockey, S. S. (2002). Low-wealth adults financial literacy, money management behavior and associates factors, including critical thinking (Doctoral thesis, Ohio State University, Utah, USA).

Sumarwan, U. (1990). A managerial system approach to factors influencing satisfaction with households' financial status (Doctoral thesis, Iowa State University, Ames, Iowa, USA).

Vlaev, I., \& Elliott, A.(2014). Financial well-being components. Social Indicators Research, 118(3), 1103-1123. doi:10.1007/s11205-013-0462-0

Vosloo, W., Fouche, J., \& Barnard, J.(2014). The relationship between financial efficacy, satisfaction with remuneration and personal financial wellbeing. International Business and Economics Research Journal, 13(6), 1455-1470. doi:10.19030/iber.v13i6.8934

Xiao, J. J., Sorhaindo, B., \& Garman, E. T. (2006). Financial behaviors of consumers in credit counseling. International Journal of Consumer Studies, 30(2), 108-121. doi:10.1111/j.1470-6431.2005.00455.x

Xiao, J. J., Tang, C., Serido, J., \& Shim, S. (2011). Antecedents and consequences of risky credit behavior among college students: Application and extension of the theory of planned behavior. Journal of Public Policy $\mathcal{E}$ Marketing, 30(2), 239-258. doi:10.1509/jppm.30.2.239 


\section{APPENDIX}

\section{INSTRUMENT CONSTRUCTS, QUESTIONS, AND SCALES}

\begin{tabular}{|c|c|c|}
\hline Construct & Questions & Scale \\
\hline \multirow{10}{*}{ 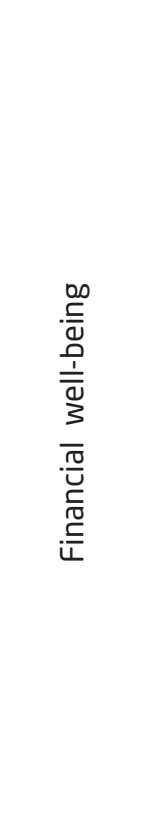 } & 1. I could handle a major unexpected expense.* & \multirow{6}{*}{$\begin{array}{l}\text { Completely, very well } \\
\text { somewhat, very little } \\
\text { not at all }\end{array}$} \\
\hline & 2. I am securing my financial future.* & \\
\hline & $\begin{array}{l}\text { 3. Because of my money situation, I feel like I will never have } \\
\text { the things I want in life. }\end{array}$ & \\
\hline & $\begin{array}{l}\text { 4. I can enjoy life because of the way I'm managing my } \\
\text { money.* }\end{array}$ & \\
\hline & 5. I am just getting by financially. & \\
\hline & $\begin{array}{l}\text { 6. I am concerned that the money I have or will save won't } \\
\text { last. }\end{array}$ & \\
\hline & $\begin{array}{l}\text { 7. Giving a gift for a wedding, birthday, or other occasion } \\
\text { would put a strain on my finances for the month. }\end{array}$ & \multirow{4}{*}{$\begin{array}{l}\text { Always, often, } \\
\text { sometimes, rarely } \\
\text { never }\end{array}$} \\
\hline & 8. I have money left over at the end of the month.* & \\
\hline & 9. I am behind in my finances. & \\
\hline & 10. My finances control my life. & \\
\hline \multirow{9}{*}{ 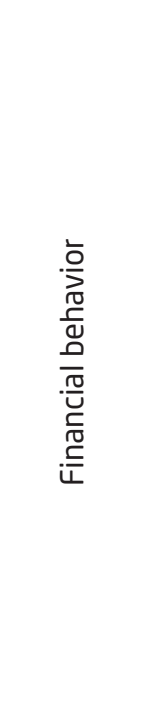 } & $\begin{array}{l}\text { 11. I take notes and control my personal expenses (e.g., } \\
\text { expense and revenue spreadsheet). }\end{array}$ & \multirow{9}{*}{$\begin{array}{l}\text { Never, almost never, } \\
\text { sometimes, almost } \\
\text { always, always }\end{array}$} \\
\hline & 12. I compare prices when buying something. & \\
\hline & 13. I have a plan for expenses / budget. & \\
\hline & 14. I pay my bills without delay. & \\
\hline & 15. I analyze my financial situation before a major purchase. & \\
\hline & 16. I save more when I get a pay rise. & \\
\hline & $\begin{array}{l}\text { 17. I save some of the money I get each month for a future } \\
\text { need. }\end{array}$ & \\
\hline & 18. I save monthly. & \\
\hline & $\begin{array}{l}\text { 19. I save regularly to achieve financial targets in the long } \\
\text { term. }\end{array}$ & \\
\hline
\end{tabular}




\section{INSTRUMENT CONSTRUCTS, QUESTIONS, AND SCALES (continuation)}

\begin{tabular}{|c|c|c|}
\hline Construct & Questions & Scale \\
\hline \multirow{8}{*}{ 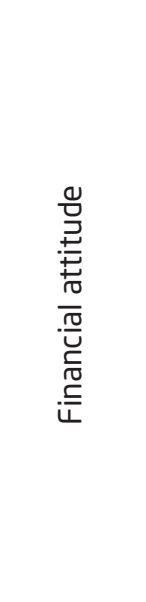 } & 20. It is important to establish financial targets for the future. & \multirow{8}{*}{$\begin{array}{l}\text { Strongly disagree, } \\
\text { disagree, indifferent, } \\
\text { agree, completely } \\
\text { agree }\end{array}$} \\
\hline & 21. The way I manage my money today will affect my future. & \\
\hline & 22. I do not worry about the future, I live only in the present. & \\
\hline & 23. Saving is impossible for our family. & \\
\hline & $\begin{array}{l}\text { 24. After deciding about money, I tend to worry too much } \\
\text { about that decision. }\end{array}$ & \\
\hline & 25. It is hard to build a family spending plan & \\
\hline & $\begin{array}{l}\text { 26. I find it more satisfying to spend money than to save for } \\
\text { the future. }\end{array}$ & \\
\hline & 27. Money is made to be spent. & \\
\hline
\end{tabular}

* Inverted scales.

\section{QUESTIONS AND ALTERNATIVES FOR FINANCIAL KNOWLEDGE}

\section{Questions}

Options

28. Imagine you have $\mathrm{R} \$ 100.00$ in a savings account and the tax rate is $10 \%$ a year. After 5 years, how much money will you have in this account?

More than $\mathrm{R} \$ 150.00$ * $^{*}$

Less than $\mathrm{R} \$ 150.00$.

Exactly $R \$ 150.00$.

Do not know.

More than today.

Exactly the same.*

Less than today.

Do not know.

30. Considering a long time period, (e.g., 10 years), which asset described below normally gives the highest rate of return?
Savings accounts.

Public securities.

\section{Stocks.*}

Do not know. 
QUESTIONS AND ALTERNATIVES FOR
FINANCIAL KNOWLEDGE (continuation)

Questions

\begin{tabular}{|c|c|}
\hline Questions & Options \\
\hline \multirow{5}{*}{$\begin{array}{l}\text { 31. Imagine five friends receive a donation of R\$1000.00 and } \\
\text { they must split the money equally between them. How much each } \\
\text { will get? }\end{array}$} & 100. \\
\hline & $200 .^{*}$ \\
\hline & 1000 \\
\hline & 5000. \\
\hline & Do not know. \\
\hline \multirow{3}{*}{$\begin{array}{l}\text { 32. An investment with a high rate of return will have high risk rate. } \\
\text { This affirmation is: }\end{array}$} & True.* \\
\hline & False. \\
\hline & Do not know. \\
\hline \multirow{3}{*}{$\begin{array}{l}\text { 33. A credit lasting } 15 \text { years typically requires higher monthly } \\
\text { payments than a } 30 \text {-year credit, but the total interest paid at the } \\
\text { end of the loan will be less. This affirmation is: }\end{array}$} & True.* \\
\hline & False. \\
\hline & Do not know. \\
\hline \multirow{3}{*}{$\begin{array}{l}\text { 34. Imagine you saw the same television at two different stores by } \\
\text { the initial price of R\$ } 1000.00 \text {. The A store offers a discount of R\$ } \\
150.00 \text {, while the B store offers a discount of } 10 \% \text {. What is the best } \\
\text { alternative? }\end{array}$} & $\begin{array}{l}\text { Buy in the A store } \\
\text { (discount of } R \$ 150.00) \text {. }^{*}\end{array}$ \\
\hline & $\begin{array}{l}\text { Buy in the B store (discount } \\
\text { of } 10 \%) \text {. }\end{array}$ \\
\hline & Do not know. \\
\hline \multirow{4}{*}{$\begin{array}{l}\text { 35. Imagine you made a loan of } \mathrm{R} \$ 10000.00 \text { to be paid after one } \\
\text { year and the total cost with interest is } \mathrm{R} \$ 600.00 \text {. The interest rate } \\
\text { you will pay this loan is: }\end{array}$} & $0.3 \%$ \\
\hline & $0.6 \%$ \\
\hline & $3 \%$ \\
\hline & $6 \% *$ \\
\hline
\end{tabular}

\section{NOTAS DOS AUTORES}

Kelmara M. Vieira, PhD from the Graduate Program in Administration, Federal University of Rio Grande do Sul (UFRGS); Aureliano A. Bressan, PhD from the Department of Agricultural Economics, Federal University of Viçosa (UFV); Luana S. Fraga, master from the Department of Administrative Sciences, Federal University of Santa Maria (UFSM).

Kelmara M. Vieira is now associate professor at the Center for Social and Human Sciences of UFSM; Aureliano A. Bressan is now full professor of Finance at the Faculty of Economic Sciences 
of Federal University of Minas Gerais (UFMG); Luana S. Fraga is now PhD student of the Graduate Program in Development Economics of Pontifical Catholic University of Rio Grande do Sul (PUCRS).

Correspondence concerning this article should be addressed to Kelmara M. Vieira, Avenida Roraima, 1000, prédio 74C, sala 4212, Camobi, Santa Maria, Rio Grande do Sul, Brazil, CEP 97105-900.

E-mail:kelmara@terra.com.br

\section{EDITORIAL BOARD}

\section{Editor-in-chief}

Gilberto Perez

Associated editor

Gardênia da Silva Abbad

Technical support

Vitória Batista Santos Silva

\section{EDITORIAL PRODUCTION}

Publishing coordination

Jéssica Dametta

Language editor

Daniel de Almeida Leão

Layout designer

Emap

Graphic designer

Libro 